\title{
Chemical composition of soil waters in oil and gas production areas of north of Western Siberia
}

\author{
Marina Opekunova, Anatoly Opekunov, Stepan Kukushkin*, and Sergey Lisenkov \\ Saint Petersburg State University, 7/9 Universitetskaya nab, 199034, St. Petersburg, Russia
}

\begin{abstract}
This study describes the changes in the chemical composition of soil waters under the influence of natural and anthropogenic factors in the area of development of oil and gas condensate fields in the north of Western Siberia. The concentration of chemical elements ( $\mathrm{Na}, \mathrm{K}, \mathrm{Ca}, \mathrm{Cu}$, $\mathrm{Zn}, \mathrm{Fe}, \mathrm{Pb}, \mathrm{Cd}, \mathrm{Ni}, \mathrm{Co}, \mathrm{Cr}, \mathrm{Ba}, \mathrm{Sr}, \mathrm{Cd}$, and $\mathrm{Mn}$ ) in soils, ground and soil waters was determined. Pollution of soil water and soil is local in nature and it is characteristic of areas located in the immediate vicinity of industrial facilities. A set of indicators is proposed for assessing the transformation of natural complexes under the influence of oil and gas production. The increased $\mathrm{pH}$ values, concentrations of petroleum hydrocarbons, nitrates, chlorides, sodium, potassium, calcium, barium, strontium, iron and manganese, as well as zinc, vanadium, cobalt and nickel are observed. In the impact zones in soil waters and soils. Mechanical disturbances of the soil and vegetation cover lead to an increase in defrost, secondary waterlogging and are accompanied by an increase in the migration of chemical elements in the catenary structure of landscapes.
\end{abstract}

\section{Introduction}

In recent years, due to global climate change, a lot of attention is paid to the problem of degradation of permafrost in the Arctic, migration of trace elements and changes in the chemical composition of natural waters [1-4]. Anthropogenic activity is imposed on climate trends in these areas. Two hundred and thirty-six oil and gas condensate fields have been discovered in the Yamalo-Nenets Autonomous Okrug (north of Western Siberia), which are currently at the stage of exploration, development and production of hydrocarbons.

Anthropogenic impact is accompanied by disturbance and pollution of landscape components. One of the main pathways for pollutants to enter water streams is surface and subsoil runoff when drilling sludge spill onto the surface. Currently, the study of warming focuses on greenhouse gas emissions, changes in the biogeochemical cycle of organic carbon and the species composition of vegetation. At the same time, thawing of permafrost

*Corresponding author: s.kukushkin@spbu.ru 
is accompanied by a change in the migration of others chemicals substances in landscapes, including trace elements related to priority pollutants.

As a result of many years of research in the north of Western Siberia $[5,6]$, active lateral migration of chemicals under intensive anthropogenic pollution was revealed, and the role of the biogeochemical barrier in the soil organic horizon in reducing the radial migration of pollutants was determined [7]. Moreover, the value of the boundary of permafrost and seasonal thawed layer (STL) in the mobilization and accumulation of metals has not yet been evaluated. The solution to this problem is necessary to determine the resistance of soils to chemical pollution and assess the flow of metals into natural waters during the degradation of permafrost.

\section{Object and methods of research}

\subsection{Study area}

The object of research is natural complexes of the polygonal tundra and northern taiga of the Nadym-Pur-Taz region, which are currently subjected to multilateral impact due to the intensive development of oil and gas fields. The studies are based on the assessment of changes in the processes of migration and accumulation of chemicals in the soil waters of the background and disturbed. For this purpose, four transect, including portions of the spill drill cuttings to enter the background position was investigated. Two transects are located within the northern taiga. Transect 1 is located on a gently sloping plain with well-drained illuvial-ferruginous clayey soils (Entic Podzols). Transect 2 crosses a gentle, slightly drained plain with peaty-gley heavy loamy soils (Histic Gleysol). Two transects are placed in polygonal tundra. They are located near exploratory well sites within the raised inclined plain of the Yamal-Gydan fault-block uplift on heavy loam (third transect) and light loam (fourth transect) soils (Spodic Cryosols).

\subsection{Sampling procedure}

On each transect, every 50 meters, four or five test sites with soil sections were laid, in which soil, ground and soil waters samples were taken. Soil solutions were selected from peat horizons of the soil by pressing. Groundwater samples were collected in the lower part of the soil profile at the level of the parent rock. A total of 23 test sites were studied, their detailed environmental characteristics were given, 47 soil samples and 36 soil and groundwater samples were taken. Water samples were separated on a CM-6M centrifuge and filtered on filter papers grade 390, then acidified with $\mathrm{HNO}_{3}$.

\subsection{Chemical analysis}

The total metals content ( $\mathrm{Na}, \mathrm{K}, \mathrm{Ca}, \mathrm{Cu}, \mathrm{Zn}, \mathrm{Fe}, \mathrm{Pb}, \mathrm{Cd}, \mathrm{Ni}, \mathrm{Co}, \mathrm{Cr}, \mathrm{Ba}, \mathrm{Sr}, \mathrm{Cd}$ и $\mathrm{Mn}$ ) in soils and natural waters is measured by inductively coupled plasma mass spectrometry (ICP-MS) in the Central laboratory of A.P. Karpinsky Russian Geological Research Institute (Saint Petersburg, Russia). The dissolution of samples is performed using concentrated nitric, hydrofluoric, and perchloric acids ( $\left.\mathrm{HF}, \mathrm{HNO}_{3}, \mathrm{HClO}_{4}\right)$. Mineralization (TDS) was analyzed by a conductometric method; the $\mathrm{pH}$ value was determined using a «Horiba» $\mathrm{pH}$ meter with a horizontal electrode for measuring solid and bulk materials and liquids. 


\section{Results and discussion}

The main factors that determine the differences in hydrochemical composition of soil water are the size and chemical composition of the soil due to the nature of parent rocks. At the same time, geochemical barriers (sorption, evaporation, oxidation, biogeochemical, anthropogenic alkaline, etc.) in the soil profiles alter the radial and lateral migration of chemical elements. No reliable relationship between the content of most of the studied chemical elements in soils and soil waters was found. The only exceptions are $\mathrm{Mn}, \mathrm{Ni}$ and Co, which is set significant correlation $(r=0,61-0,66)$. The absence of a correlation of metals between the solid and dissolved phases indicates that soil water is an unstable physicochemical system. The forms of the presence of metals in this system are determined by $\mathrm{pH}$, the lability of organic matter, and phase transitions are due to the action of geochemical barriers, the nature and intensity of which vary depending on the degree of anthropogenic load.

In addition, zonal-climatic conditions have a great influence on the elemental composition of soil waters. The content of most chemical elements $(\mathrm{Cu}, \mathrm{Zn}, \mathrm{Pb}, \mathrm{Cd}, \mathrm{Ni}, \mathrm{Co}$, $\mathrm{Ba}, \mathrm{Sr}, \mathrm{Cd}$ and $\mathrm{Mn}$ ) in the ground and soil waters of the background areas decreases during the transition from tundra to northern taiga landscapes, which was also noted by other researchers [8]. An exception is $\mathrm{Na}$, the concentration of which increases in the studied waters from north to south. The content of $\mathrm{K}$ and $\mathrm{Ca}$ in permafrost, as well as $\mathrm{K}, \mathrm{Fe}$ and $\mathrm{Cr}$ in groundwater does not vary with the change of natural zones.

In connection with global climate change and a possible increase in the migratory capacity of chemical elements with increased seasonal defrosting, of great interest is a comparative analysis of the chemical composition of STL soil water and permafrost layers. Studies have shown that the $\mathrm{pH}$ value of thawed water in the layer of permafrost is higher than in the thawed soil horizon. This was determined both in the peat soils of the northern taiga and in the polygonal peatlands (table 1). In a STL, a clear differentiation of the chemical composition of sediments in depth is observed: migration of the easily moving $\mathrm{Na}$ and $\mathrm{K}$ and accumulation of lithophilic and siderophilic elements are observed.

The coefficient of freezing is proposed to assess changes in the chemical composition of soil water of STL and the frozen layer (1).

$$
\kappa_{F}=C_{\mathrm{F}} / C_{\mathrm{SW}}
$$

where $C_{\mathrm{F}}$ is the element total content in the soil water of permafrost lower; $C_{\mathrm{SW}}$ is the element total content in the soil water.

According to the $K_{F}$ value, three groups of chemical elements are distinguished. Under the background conditions in the northern taiga and polygonal tundra, the $K_{F}$ value of $\mathrm{Na}$ and $\mathrm{Cd}$ is close to 1 . The value of $K_{F} \mathrm{~V}, \mathrm{Cr}, \mathrm{Mn}, \mathrm{Fe}, \mathrm{Ba}$, and $\mathrm{Co}$ exceeds 1 , which indicates their fixation in the soil-absorbing complex of soils of STL. The value of $K_{F} K, N i$ and $\mathrm{Zn}$ is less than 1, which indicates their increased migratory ability. The ratio of $\mathrm{Cu}, \mathrm{Sr}$, and $\mathrm{Pb}$ in water of permafrost layer and STL changes during the transition from the northern taiga to polygonal tundra. The value of $K_{F} \mathrm{Cu}$ in the taiga is close to 1 , and it decreases to the north. The distribution of $\mathrm{Pb}$ and $\mathrm{Sr}$ in soil waters has a similar, but more pronounced regularity: their $K_{F}$ value in taiga is $>1$ and significantly decreases to $<1$ in polygonal tundra.

Pollution of soils, soil and groundwater is localized near industrial sites [4, 5]. A high concentration of all the metals studied, as well as an increase in the $\mathrm{pH}$ value and total mineralization are observed in the soil waters in the impact zone of the northern taiga (Table 1). A decreasing series of values of the coefficients of anthropogenic concentration (the ratio of the concentration of metals in soil water in the impact zone to their content in 
water in the background area) is as follows: $\mathrm{Na}(39)>\mathrm{Sr}(38)>\mathrm{V}(34)>\mathrm{Ba}(18)>\mathrm{Pb}(12)$ $>\mathrm{Mn}(9,4)>\mathrm{Fe}(8,3)>\mathrm{Cr}(6,8)>\mathrm{Co}(5,8)>\mathrm{Ca}(5,6)>\mathrm{Cu}(5,3)>\mathrm{Zn}(4,0)>\mathrm{K}(2,2)>\mathrm{Ni}$ $(2,0)>\mathrm{Cd}(1,6)$.

The main indicators of pollution are $\mathrm{Na}, \mathrm{Sr}, \mathrm{V}, \mathrm{Ba}$. In the polygonal tundra, a similar distribution of metals is noted: $\mathrm{Na}(30)>\mathrm{Sr}(22)>\mathrm{Ca}(20)>\mathrm{Co}(16)>\mathrm{Mn}(15)>\mathrm{Ba}(9,5)$ $>\mathrm{Zn}(8,3)>\mathrm{Fe}(6,2)>\mathrm{Ni}(3,0)>\mathrm{Cd}(1,8)>\mathrm{K}(1,9)$. Pollution indicators are $\mathrm{Na}, \mathrm{Sr}$ and $\mathrm{Ba}$. The background content of $\mathrm{V}$ and $\mathrm{Cr}$ is very contrasting and requires further study. Therefore, these metals are not included in the presented series of anthropogenic concentration coefficients.

Table 1. Physical and chemical parameters and the elements content in the soil waters of northern taiga and tundra landscapes.

\begin{tabular}{|l|c|c|c|c|}
\hline \multirow{2}{*}{$\begin{array}{l}\text { Indicators } \\
\text { and elements }\end{array}$} & \multicolumn{2}{|c|}{ Northern taiga landscape } & \multicolumn{2}{c|}{ Landscapes of polygonal tundra } \\
\cline { 2 - 5 } & Disturbed sites & Background sites & Disturbed sites & Background sites \\
\hline $\mathrm{pH}$ & $3,87-7,91$ & $3,20-4,72$ & $4,16-5,53$ & $3,86-4,78$ \\
\hline $\mathrm{TDS}, \mathrm{mg} / \mathrm{l}$ & $137-2020$ & $25,2-112$ & $84,4-6290$ & $32-114$ \\
\hline $\mathrm{Na}, \mathrm{mg} / \mathrm{l}$ & $23,8-525$ & $1,47-8,44$ & $3,22-974$ & $3,21-16,2$ \\
\hline $\mathrm{K}, \mathrm{mg} / \mathrm{l}$ & $3,55-12,4$ & $1,56-6,47$ & $0,75-8,49$ & $1,79-3,88$ \\
\hline $\mathrm{Ca}, \mathrm{mg} / 1$ & $0,48-21,0$ & $0,21-0,94$ & $1,58-92,4$ & $0,395-8,4$ \\
\hline $\mathrm{Fe}, \mathrm{mg} / \mathrm{l}$ & $2,01-64,9$ & $0,46-1,61$ & $3,61-307$ & $1,14-2,65$ \\
\hline $\mathrm{V}, \mathrm{ug} / \mathrm{l}$ & $6,18-97,8$ & $1,64-4,38$ & $0,38-6,82$ & $0,73-10,4$ \\
\hline $\mathrm{Cr}, \mathrm{ug} / 1$ & $5,68-37,4$ & $2,05-6,29$ & $2,17-25,5$ & $2,16-5,88$ \\
\hline $\mathrm{Mn}, \mathrm{ug} / 1$ & $27,1-717$ & $11,6-80,3$ & $301-13300$ & $49,7-138$ \\
\hline $\mathrm{Co}, \mathrm{ug} / \mathrm{l}$ & $1,75-14,4$ & $0,79-2,1$ & $11,2-439$ & $1,68-10,7$ \\
\hline $\mathrm{Ni}, \mathrm{ug} / 1$ & $4,29-32,9$ & $2,03-7,67$ & $10,4-310$ & $4,94-12,2$ \\
\hline $\mathrm{Cu}, \mathrm{ug} / 1$ & $10,3-122$ & $4,44-26,6$ & $4,02-57,9$ & $6,78-81,2$ \\
\hline $\mathrm{Zn}, \mathrm{ug} / \mathrm{l}$ & $30,2-114$ & $5,59-41,7$ & $62-991$ & $24,9-175$ \\
\hline $\mathrm{Sr}, \mathrm{ug} / 1$ & $41,9-4600$ & $12,7-35,8$ & $38,6-4750$ & $9,89-394$ \\
\hline $\mathrm{Cd}, \mathrm{ug} / 1$ & $0,32-0,63$ & $0,17-0,36$ & $0,37-2,18$ & $0,25-0,74$ \\
\hline $\mathrm{Ba}, \mathrm{ug} / \mathrm{l}$ & $57-5070$ & $22,1-65,4$ & $240-8390$ & $66,8-182$ \\
\hline $\mathrm{Pb}, \mathrm{ug} / \mathrm{l}$ & $3,78-32,1$ & $0,82-2,68$ & $0,91-6,46$ & $1,27-5,41$ \\
\hline
\end{tabular}

The lateral migration of metals in the direction of runoff is clearly visible in the northern taiga landscape (Fig. 1). The gradual decrease metal concentrations in soil waters occurs as the distance from the source. The excess of the background for most of the studied elements is detected at a distance of 50-150 m. Lateral migration in the landscapes of the tundra zone is less pronounced, since the site is located within the subhorizontal surface (Fig. 2). Here, the migration of elements is determined by the features of the microrelief. However, the general trend of a decrease in the concentration of pollutants with distance from the source remains.

According to the results of our studies, the thickness of the seasonally thawed layer has a significant effect on the radial migration of pollutants. In the northern taiga in peat-gley soils, the depth of the STL in the impact area reaches $2 \mathrm{~m}$. A complex barrier is formed in the organogenic soil horizon, including biogeochemical, alkaline, evaporation, and sorption-hydroxide ones. The latter is due to the influx of glue waters to the surface of the evaporation barrier [9]. With this stream, a large amount of $\mathrm{Fe}^{2+}$ enters the surface, which forms hydroxides in the oxidation zone. In tundra landscapes, a STL has a lower thickness $(0.2-0.9 \mathrm{~m})$, which prevents the secondary geochemical differentiation of the soil section, as 
well as the localization of geochemical barriers and promotes active radial migration of metals.
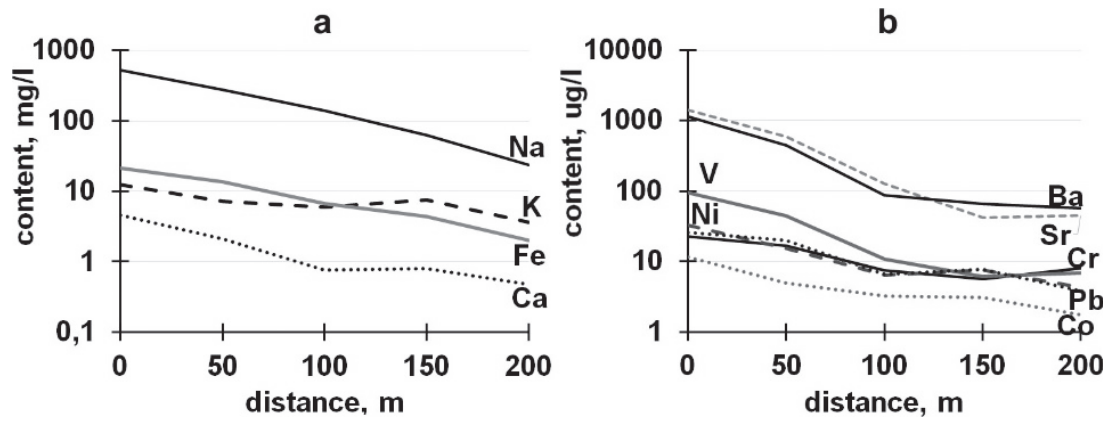

Fig. 1. Change in the content of elements in the soil waters of northern taiga landscapes when moving away from the source of pollution ( $a$ - macroelements; $b$ - trace elements).

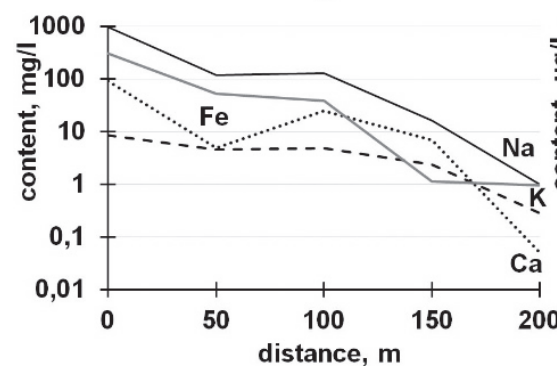

b

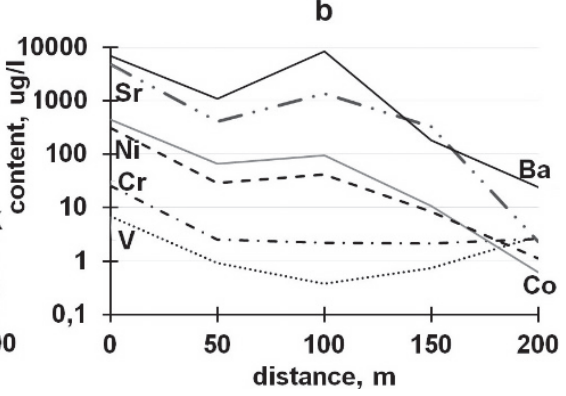

Fig. 2. Change in the content of elements in the soil waters of tundra landscapes when moving away from the source of pollution ( $\mathrm{a}$ - macroelements; $\mathrm{b}$ - trace elements).

\section{Conclusion}

The conducted studies indicate complex processes of formation and instability of the elemental composition of soil waters in the conditions of permafrost in the north of Western Siberia. The decisive effect on the migration and accumulation of metals is exerted by sorption-hydroxide, biogeochemical, evaporation and anthropogenic alkaline geochemical barriers, as well as STL thickness. Anthropogenic activity leads to a significant transformation of soil waters composition. With chemical pollution, the radial migration of pollutants is limited by the action of geochemical barriers. According to our data, which require further confirmation, vertical migration decreases with an increase in the power of the STL. Lateral migration is well expressed in geochemical conjugation along runoff hollows. On a subhorizontal surface, the lateral differentiation of chemical elements is subordinate to the microrelief. However, the distribution of pollutants is limited and, according to our data, does not exceed $150 \mathrm{~m}$. Thawing of permafrost enhances, first of all, the migration ability of $\mathrm{Na}, \mathrm{K}, \mathrm{Ni}, \mathrm{Sr}, \mathrm{Zn}, \mathrm{Cu}$, and to a lesser extent $\mathrm{Ca}, \mathrm{Ba}, \mathrm{Fe}, \mathrm{Mn}, \mathrm{Cd}$, Co.

The studies were supported by the RFBR grant 19-29-05081 "Soils of oil and gas areas in the north of Western Siberia: resistance to chemical pollution and the potential for self-purification in a changing climate». 


\section{References}

1. M.L. Bagard, F. Chabaux F, O.S. Pokrovsky, J. Viers, A.S. Prokushkin, P. Stille, S. Rihs, A.D. Schmitt, B. Dupre, Geochim. Cosmochim. Acta, 75, 3335 (2011).

2. A.J. Barker, T.A. Douglas, A.D. Jacobson, J.W. McClelland, A.G. Ilgen, M.S. Khosh, G.O. Lehn, T.P. Trainor, Chem. Geol. 381, 180 (2014).

3. I.V. Krickov, O.S. Pokrovsky, R.M. Manasypov, A.G. Lim, L.S. Shirokova, J. Viers, Geochim. Cosmochim. Acta, 265 (2019).

4. R.S. Vasilevich,. Geochem. Int. 56, 1276 (2018).

5. A. Y. Opekunov, M.G. Opekunova, S.Y. Kukushkin, A.G. Ganul, Vestn. S.-Peterb. Univ. Ser VII. 4, 87 (2012).

6. M.G. Opekunova, A.Y. Opekunov, S.Y, Kukushkin, I.Y. Arestova, Contemp Probl Ecol. 11, 99 (2018).

7. E.D. Lodygin Eurasian Soil Sci. 52, 769 (2019).

8. T.V. Raudina, S.V. Loiko, A. Lim, R.M. Manasypov, L.S. Shirokova, G.I. Istigechev, D.M. Kuzmina, S.P. Kulizhsky, S.N. Vorobyev, O.S. Pokrovsky, Sci Total Environ. 634,1004 (2018).

9. O.D. Tregubov, Vestn Mosk Univ Ser V. 3, 70 (2017). 